Idris Mahmudy, Metodologi Pembaharuan Hukum Islam dalam Perspektif ...

\section{METODOLOGI PEMBAHARUAN HUKUM ISLAM}

\section{DALAM PERSPEKTIF PEMIKIRAN HAZAIRIN}

\section{Idris Mahmudy}

Pengadilan Tinggi Agama Riau, Pekanbaru

\section{Abstract}

The Methodology of Innovation of Islamic Laws in the Perspective of Hazairin : Islamic laws were made and established in order to achieve people's prosperity (maslahat'ummah). Laws which are ta'abbudi have been put in detail; therefore the issue of faith has no longer become a reasoning competence. Laws in the area of mu'amalah in accordance with the revelation and logic (ra'yu) have been used as a means of struggle to gain prosperity because these laws are flexible in nature, perfect (takamul), balanced (tawazun), harmonious, dynamic and also balanced with all their components. It means that they are up to date, not rigid and not static. Hazairin is one of the figures of the innovation of Islamic laws in Indonesia who was involved in studying contemporary issues using a deductive method and employing normative analysis and sociological, anthropological approach.

Keywords: Islamic laws, Innovation, Ijtihad.

\section{Pendahuluan}

Manusia sebagai makhluk Tuhan selalu menghadapi pelbagai masalah dan upaya penyelesaiannya sangat bergatung kepada tekad dan kesanggupan manusia untuk memecahkan masalah yang kompleks dalam kehidupannya. Penelitian memegang peranan penting dalam membantu manusia untuk memperoleh pengetahuan baru dalam memecahkan masalah, disamping akan menambah ragam pengetahuan lama. ${ }^{1}$

Jalan mencari hukum Islam melalui usaha sungguh-sungguh (ijtihad) dapat dilakukan tergantung kepada obyek yang akan diteliti

${ }^{1}$ Bambang Sungono, Metodologi Penelitian Hukum, (Jakarta: PT. Raja Grafindo Persada, 2002), hlm. 2
Al-Fikra: Jurnal Ilmiah Keislaman, Vol. 5, No. 2, Juli-Desember 2006

dalam rangka mencari hukumnya. Apakah cukup dengan qiyas atau harus mempergunakan metode lainnya, seperti istihsan, istishab, maslahah mursalah dan lainnya. Hal ini sangat tergantung kepada ilmu, pengalaman, kebijakan dan kearifan para pakar untuk memilih salah satu metode yang paling tepat untuk suatu masalah tertentu. Pembentukan hukum Islam ditujukan untuk mewujudkan maslahat 'ammah. Hukum-hukum yang ta'abbudi sudah terperinci dan bukan lagi kompetensi akal. Hukum-hukum yang bukan akidah dan bukan pula ta'abbudi yaitu dalam bidang mu'amalah, dengan berpegang kepada tuntunan wahyu, akal sehat ( $\left.r a^{\prime} y u\right)$ turut berperan dalam berijtihad untuk mewujudkam kemaslahatan. Hukum Islam mempunyai tabi'at yang fleksibel, takamul, ketuntasan tentang pandangan hidup, juga mempunyai tabi'at tawazun (wasathiyyah), yaitu harmonis, seimbang antara semua yang menjadi komponennya, dan bertabi'at harakah (dinamis), yaitu bergerak maju untuk menjawab tantangan zaman, tidak beku dan statis, dengan catatan tidak lepas dari prinsip dan tidak menyimpang dari rel yang digariskan Syara', ada batas-batas yang boleh bergerak dan ada batas-batas yang tidak boleh dilampaui. ${ }^{2}$

Hukum merupakan refleksi dari tata nilai yang diyakini masyarakat sebagai suatu pranata dalam kehidupan bermasyarakat, berbangsa dan bernegara. Oleh karena itu muatan hukum selayaknya mampu menangkap aspirasi masyarakat yang tunbuh dan berkembang bukan hanya yang bersifat kekinian, melainkan juga sebagai acuan dalam mengantisipasi perkembangan sosial, ekonomi, dan politik di masa depan. Oleh karena itu hukum bukan sekedar norma statis yang mengutamakan kepastian dan ketertiban, tetapi juga norma-norma yang harus mampu mendinamisasi pemikiran dan merekayasa perilaku masyarakat dalam mencapai cita-citanya(law as a tool of social engineering). ${ }^{3}$

\section{Biografi Hazairin}

2 Ahmad Djatnika, Jalan Mencari Hukum Islam, (Jakarta: PP IKAHA, 1994), hlm. 143

${ }^{3}$ Bustanul Arifin, Prospek Hukum Islam, (Jakarta: PP IKAHI Pusat, 1994), hlm. xxi. 
Idris Mahmudy, Metodologi Pembaharuan Hukum Islam dalam Perspektif ...

Nama lengkap Hazairin adalah Hazairin Gelar Pangeran Alamsyah Harahap, lahir di Bukit Tinggi 28 Nopember 1906, dan wafat 12 Nopember 1975.

Hazairin seorang tokoh yang tidak asing lagi bagi masyarakat Indonesia terutama bagi para peminat atau pemerhati hukum, baik hukum umum maupun hukum Islam. Dia termasuk salah seorang pakar yang mempunyai kelebihan yang luar biasa. Pada dirinya melekat dua keahlian, yaitu pakar hukum adat skaligus pakar hukum Islam. Kedua keahlian ini berjalan seiring dan sama-sama menonjolnya 4 .

Suatu hal yang sangat perlu dikaji, adalah kenapa sosok Hazairin yang dikenal sebagai orang yang menekuni pendidikannya di lembaga pendidikan umum, dan tidak pernah tercatat belajar secara formal pada lembaga pndidikan Islam, mampu menjadi seorang pakar hukum Islam terkenal (menurut penulis ia Mujtahid Muntasib Indonesia). Dipihak lain apabila diperhatikan nama Hazairin lebih populer di dunia perguruan tinggi (akademikus) dibandingkan dengan kiprahnya di pentas politik (politisi), padahal Hazairin pernah menjabat sebgai Menteri Dalam Negeri, pada Kabinet Ali SostroamidjoyoWongsonegoro(1953 - Oktober 1954) ${ }^{5}$.

Umat Islam Indonesia patut berterima kasih atas segala upaya dan hasil perjuagan yang dipersembahkan Hazairin sepanjang hidupnya kepada nusa, bangsa dan agama. Dia salah seorang tokoh yang begitu gigih berada di garda depan menyuarakan dan membela keberadaan hukum Islam agar hukum Islam bisa dilaksanakan di bumi nusantara. Hazairin tampil dengan suara keras, ketika Senouck Hurgronye lewat teori receptie yang diberi cap oleh Hazairin dengan nama teori Iblis, serta melancarkan usaha-usaha untuk menggusur eksistensi hukum Islam di bumi Indonesia. Dan dengan secara perlahan-lahan menggerogoti wewenang Peradilan Agama. Hazairin menghujat teori Senouck Hurgronye, karena teori tersebut menghalang-halangi berlakunya hukum Islam di Indonesis seraya

${ }^{4}$ Sayuti Thalib, Politik Hukum Baru, (Bandung: Bina Cipta, 1987), hlm. 37.

${ }^{5}$ Mohamad Daud Ali, Hukum Islam, (Jakarta: PT. Raja Grafindo Persada, 2004), hlm. 244.
Al-Fikra: Jurnal Ilmiah Keislaman, Vol. 5, No. 2, Juli-Desember 2006

mengajak umat Islam untuk tidak mematuhinya dan tetap melaksanakan perintah Allah dan RasulNya .

Hazairin juga berusaha keras menggedor pintu Ijtihad yang sudah lama dikunci oleh umat Islam. Dia mengkritik sikap taklid ulama yang menjadi penyebab utama kebekuan pemikiran fikih bukan hanya karena hukum fikih diproduksi oleh para teoritisi hukum di belakang meja, dan bukan oleh praktisi hukum di lapangan, sebagai akibatnya hukum fikih tidak berkembang dan statis, sementara dipihak lain kemajuan iptek bergulir begitu pesat dan cepat, lebih parah lagi ulama menganggap bahwa kitab-kitab itu begitu suci dan keramat sehigga mampu menggantikan kedudukan al-Quran. Hazairin mengatakan bahwa manusia tanpa sengaja telah menambah rukun iman yakni beriman kepada ulama masa lalu, padahal pemikiran mereka itu tidak dapat terjamin kekal, dan aktual sepanjang zaman. Ini berarti kelambatan berlakunya al-Quran disemua tempat dan zaman. Menurut Hazairin hanya dengan menghilangkan taklid dan membuka pintu Ijtihad kita dapat dengan mudah dan sempurna mempertautkan hukum adat dengan kehendak Ilahi. Oleh karena itu perlu dikaji ulang terhadap fikih yang ada sekarang ini ${ }^{6}$.

Hazairin tampil memformulasikan pikiran-pikiran segarnya yang di sesuaikan dengan watak dan budaya masyarakat Indonesia dan mengajukan berbagai konsepnya, mulai dari bidang perkawinan, bidang kewarisan, pidana Islam, politik, hingga demokrasi Pancasila dan lain-lain. Kesemua hasil pikiran-pikiran yang ditawarkan itu telah ikut memperkaya khazanah keilmuan Indonesia.

Singkatatnya kiprah Hazairin di dunia Perguruan Tinggi, di tengah-tengah kehidupan umat Islam, serta di dunia politik itulah yang telah menghantarkan namanya pada posisi yang penting. Oleh karena itu sudah sepantasnya bila perjalanan hidup serta percikan-percikan pemikirannya kembali diangkat untuk mengambil hikmah dan model perjuangan membangun bangsa Indonesia.

\section{Pendidikan Hazairin}

${ }^{6}$ Abdul Aziz Dahlan, Ensiklopedi Hukum Islam, (Jakarta: PT. Ichtiar Baru Van Hoeve, 1994), Jilid 2, hlm. 538-539. 
Idris Mahmudy, Metodologi Pembaharuan Hukum Islam dalam Perspektif ...

a. Pendidikan formal

Walaupun Hazairin dilahirkan di Bukit Tinggi, namun pendidikan formalnya tidak diawali di kota kelahirannya, melainkan di Bengkulu. Pendidikan formalnya adalah HIS (Hollands Inlansche School) di Bengkulu, tamat tahun 1920. Kemudian Hazairin melanjutkan pendidikannya ke sekolah MULO (Meer Uitgebreid Lagere Onderwijs) di Padang, dan tamat tahun 1924. Dalam usia 18 tahun, Hazairin meneruskan pendidikannya ke AMS (Algemene Middelbare School) di Bandung, dan berhasil lulus tahun 1927.

Setelah tamat AMS, Hazairin hijrah ke Batavia (Jakarta) dan meneruskan studinya di RHS (Rechtkundige Hooge school) yang merupakan sekolah tinggi hukum adat, selama delapan tahun, dia berkutat mendalami bidang adat dan berhasil meraih gelar Messter in de Rechten $(\mathrm{Mr}$,) tahun 1935 ?

b. Pendidikan Agama

Hazairin disamping belajar pendidikan umum dia juga belajar pendidikan Agama dan bahasa Arab dari ayah dan kakeknya untuk memahami lebih mendasar dan mendalam Syari'at Islam dan dilanjutkan dengan self study. Hazairin mnguasai bahasa Belanda, Inggeris, dan Perancis secara aktif dan bahasa Arab Jerman dan Latin secara fasif.

Hazairin bukanlah orang mudah merasa puas, sehingga sarjana hukum yang diraihnya belum merasa cukup baginya dan ingin meraih gelar yang lebih tinggi. Begitu ada kesempatan dia memanfaatkannya dengan penuh optimis. Hazairin mendapat tugas baru untuk mengadakan penelitin lapangan mengenai Adat Rejang, salah satu suku yang terdapat di Keresidenan Bengkulu. Penelitian ini dilakukannya sebagai syarat untuk meraih gelar Doktor dalam bidang hukum adat. Penelitian ini dilakukan di bawah bimbingan promotor Mr. B Ter Haar, pakar hukum adat terkenal masa itu. Berkat kegigihan dan keuletannya, hanya dalam waktu yang sangat singkat, tidak lebih dari tiga bulan, penelitin itu telah berhasil dirampungkannya. Hasil penelitian itu yang merupakan Disertasinya yang berjudul "De

${ }^{7}$ Ibid, hlm. 537.
Al-Fikra: Jurnal Ilmiah Keislaman, Vol. 5, No. 2, Juli-Desember 2006 Rejang" yang telah mengantarnya meraih gelar Doktor pada tanggal 29 Mei $1936^{8}$.

Hazairin pada saat meraih gelar Doktor berusia 30 tahun relatif masih muda dan gelar Doktor dalam bidang hukum adat hanya satu satunya pada saat itu disandang oleh Hazairin buat penduduk bumi putra di Sekolah Tinggi Hukum Adat Batavia. Dengan karya itulah Hazairin menjadi seoarang ahli hukum adat.?

\section{Karir Hazairin}

Setelah Hazairin meraih gelar sarjana hukum, dan kemudian diangkat sebagai asisten dosen hukum adat dan etnologi (antropologi) pada Sekolah Tinggi Ilmu Hukum di Batavia (Jakarta) tahun 19351938. Melihat akan kecakapan dan kedisplinannya, kemudian pemerintah Belanda mengangkatnya sebagai pegawai yang diperbantukan pada Ketua Pengadilan Negeri Padang Sidempuan, Sumatera Utara sekaligus sebagai pegawai Penyidik Hukum Adat Tapanuli (1938-1942). ${ }^{10}$

Tugasnya di kota ini terus berlanjut, walaupun Belanda kemudian digantikan kedudukannya oleh Jepang. Ketika Jepang berkuasa, Hazairin malah diangkat sebagai penasehat hukum pada penguasa Jepang. Tugas ini dipangkunya sampai Indonesia merdeka (1942 1945). Setelah kemerdekaan Hazairin terus melanjutkan tugasnya di Tapanuli Selatan. Selama selang waktu enam bulan (Oktober 1945April 1946) ia menjabat Ketua Pengadilan Negeri Tapanuli Selatan merangkap Ketua Komite Nasional Indonesia (KNI) Dan anggota pusat pemerintahan Tapanuli, Asisten Residen dan Kepala Luhak. Setelah bertugas di Tapanuli Selatan selama 11 tahun ia dipindahkan oleh pemerintah pusat ke daerah asalnya, Bengkulu. Atas prestasinya lalu ia dipromosikan menjadi Residen Bengkulu(1946- 1950), merangkap Wakil Gubernur Militer Sumatera Selatan hingga tahun

8 Iskandar Ritonga, Hazairin Gelar Pangeran Alamsyah Harahap, Mimbar Hukum Nomor 44, (Jakarta: Dipbinbapera Islam, 1999), hlm. 65.

${ }^{9}$ Ibid, hlm. 67

10 Abdul Aziz Dahlan, Ensiklopedi Hukum Islam, Jakarta: PT. Ichtiar Baru Van Hoeve, 1994), jilid 2, hlm. 538 
Idris Mahmudy, Metodologi Pembaharuan Hukum Islam dalam Perspektif ...

1953. Selanjutnya ditarik ke Jakarta untuk menjabat Kepala Bagian (Kabag) Hukum Sipil/Perdata pada Kementerian Kehakiman $1953{ }^{11}$.

\section{Hazairin Berpartai Politik}

Ketika bangsa Indonesia berjuang mati-matian untuk merebut kemerdkaan, Hazairin juga tidak tinggal diam. Dia dan kawankawannya di Tapanuli Selatan berjuang sebagai anggota gerakan bawah tanah di zaman infiltrasi Jepang tahun 1945. Kemudian Hazairin bergabung dengan Tentara Pelajar, baik ketika berada di Tapanuli Selatan maupun setelah ia berada di Bengkulu (1945-1950)

Selain ia sebagai pejuang, ia dikenal pula sebagai politisi. Ia pernah memimpin Partai Indonesia Raya (PIR). Kemudian ia dipercaya untuk memangku jabatan Menteri Dalam Negeri (Agustus 1953 - 18 Nopember 1954) dalam Kabinet AlisastroamidjoyoWongsonegoro (1953-1954). Kemudian PIR terbelah dua PIR yang dipimpin Hazairin dan PIR yang dipimpin oleh Wongsonegoro. Perpecahan itu muncul disebabkan terjadinya perbedaan pandangan dalam menyikapi kebijakan ekonomi yang dilancarkan oleh Menteri Ekonomi Mr. Iskak Tjokrohadisuyo (PNI) yang dinilai partai oposisi (Masyumi) sebagai plitik ekonomi nasionalis Indonesia yang lebih memberi kesempatan etnis Cina daripada pribumi. ${ }^{12}$

Perbedaan pandangan antara pemeritah dan partai-partai oposisi di DPR menyangkut kebijakan ekonomi sebagai pemicu terjadinya perpececahan di tubuh PIR. Dalam rapat DPP PIR dengan anggotaanggota fraksinya yang ada di Parlemen pada tanggal 21 Juli 1954, anggota-anggota fraksi itu menuntut supaya Menteri-Menteri dari PIR ditarik dari kabinet. Ternyata, kebanyakan dari anggota fraksi itu adalah penganut atau pendukung Hazairin. Rupanya mereka sependapat dengan kecaman-kecaman yang dilontarkan partai oposisi (Masyumi) di dalam Parlemen terhadap kebijakan ekonomi yang dilakukan Menteri Perekonomian.
Al-Fikra: Jurnal Ilmiah Keislaman, Vol. 5, No. 2, Juli-Desember 2006

Tuntutan penarikan Menteri-Menteri PIR itu ditentang oleh Wongsonegoro, yang mempunyai dukungan kuat terutama cabangcabang partainya di Pulau Jawa. Begitulah perpecahan itu tidak terhindari lagi, sehingga PIR terpecah dua. Perpecahan ini kata Alisastroamidjoyo, agak menyulitkan pemeintah, karena dari dua puluh suara PIR di Parlemen, kebayakan pendukung pendukung setia atau penganut garis politik Hazairin. Adanya mosi tidak percaya dari partai lainnya, ditambah dengan derasnya usulan penarikan MenteriMenteri yang mewakili PIR di Parlemen, maka pada tanggal 18 Nopember 1954, dengan sangat terpaksa, Kabinet Ali-Wongsonegoro terpaksa dirombak (reshuffle) besar-besaran dan termasuk yang diganti itu adalah Hazairin, Menteri Dalam Negeri. ${ }^{13}$

Setelah berhenti dari Menteri Dalam Negeri, ia diangkat sebagai pejabat tinggi yang diperbantukan pada Kementerian Kehakiman (1954-1959) dan Kementerian Pendidikan, Pengajaran dan Kebudayaan, serta sebagai guru besar ilmu hukum di berbagai Perguruan Tinggi.

\section{Hazairin Mengabdi di Dunia Ilmiah}

Dunia politik bagi Hazairin bukanlah lahan yang tepat, karena ia hanya mampu bertahan dalam mengarungi kancah politik itu selama enam tahun saja (1948-1954). Hal ini disebabkan bukan saja karena faktor garis politikya yang berhaluan keras atau perinsipnya yang sangat tegas dan tidak ada tawar-menawar, tetapi juga karena situasi politik yang tidak memungkinkan pada saat itu, sehingga Hazairin memilih dunia ilmiah

Sejak itu Hazairin mengabdikan seluruh hidupnya untuk mengembangkan ilmu pengetahuan yang dianggap cocok dan serasi dengan kepribadiannya, sehingga Hazairin terkenal sebagai seorang ilmuan dibanding politisi. Di kalangan Perguruan Tinggi saat itu, nama Hazairin cukup terkenal. Dia menjadi guru besar Hukum Adat dan Hukum Islam di Universitas Indonesia (UI), Universitas Islam Jakarta 
Idris Mahmudy, Metodologi Pembaharuan Hukum Islam dalam Perspektif ...

(UIJ), Perguruan Tinggi Hukum Militer (PTHM), dan Perguruan Tinggi Ilmu Kepolisian (PTIK). ${ }^{14}$

Obsesinya dalam dunia pendidikan cukup tinggi, karena memang bukankah hanya lewat lembaga pendidikan kualitas bangsa Indonesia akan dapat ditingkatkan, akan tetapi juga lembaga ini merupakan sarana yang sangat efektif untuk mentransmisikan sebuah gagasan. Dalam merealisasikan cita-citanya itu pada tahun 1950, ia mendirikan Yayasan waqaf Perguruan Tinggi Islam Jakarta yang melahirkan Universitas Islam Jakarta (UID) dimana ia dipercayakan sebagai ketua Yayasan merangkap sebagai Rektornya samapi ia wafat. Selain itu ia salah seorang anggota Dewan Kurator IAIN Syarif Hidayatullah Jakarta (1960-hingga ia wafat). Dan pada tahun 1962 Hazairin ikut membidani lahirnya Majelis Ilmiah Islamiyah yang langsung dipercaya sebagai ketuanya.

\section{Hazairin Penulis Produktif}

Hazairin setidaknya mewariskan tujuh belas buah karya, diantaranya:

a. De Rejang (Disertasi Doktoralnya 1936)

b. De Gerolgen Van De Howeijksont Binding in Zuid Tapanuli (akibat perceraian Perkawinan di Tapanuli Selatan, 1941)

c. Reorganisasi Vanhet Rechtswesen In Zuid Tapanuli (Reorganisasi Hukum di Tapanuli Selatan)

d. Pergolakan Penyesuaian Adat Kepada Hukum Islam (1958)

e. Hukum Keluarga Nasional (1962)

f. Hukum Kewarisan Bilateral Menurut al-Qur an (1968)

g. Hendak Kemana Hukum Islam (1960)

h. Hukum Pidana Islam Ditinjau Dari Segi Dasar-dasar dan Asas-asas Tata Hukum Nasional Demokrasi Pancasila (1970) dan Negara Tanpa Penjara

i. Tujuh Seragakai tentang Hukum (1973) dan

j. Tinjauan Mengenai Undang-undang Perkawinan Nasional (No. 1 th 1974) ${ }^{15}$
Al-Fikra: Jurnal Ilmiah Keislaman, Vol. 5, No. 2, Juli-Desember 2006

\section{Pemikiran Pembaharuan Hukum Islam}

Hazairin salah seorang yang gigih menyuarakan dan memperjuangkan pemberlakuan hukum Islam di Indonesia, ia mengatakan bahwa bangsa Indonesia akan bahagia apabila hukum yang berlaku di ngara ini adalah Syaria't agama atau sekurangkurangnya hukum yang tidak bertentangan dengan Syari'at agama.

Hazairin menyerukan agar pintu Ijtihad dibuka lebar dengan harapan akan lahir Mujtahid-Mujtahid Islam yang tangguh serta menguasai ilmu kemasyarakatan antara lain ilmu antropologi. Hazairin melancarkan kritik terhadap sikap taklid di antara Ulama yang menjadi penyebab utama kebekuan pemikiran fikih, bukan hanya karena hukum fikih diproduksi oleh para teoritisi hukum di belakang meja dan bukan oleh praktisi hukum di lapangan. Sebagai konsekwensinya hukum fikih terhambat perkembangannya selama lebih kurang seribu tahun. Di pihak lain kemajuan iptek bergulir begitu pesat dan cepat Lebih parah lagi ada Ulama yang menganggap bahwa kitab-kitab fikih itu begitu suci dan keramat sehingga mampu menggantikan al-Qur'an. Ia mengatakan bahwa manusia tanpa sengaja telah menambah rukun iman, yakni beriman kepada Ulama masa lalu, padahal pemikiran mereka itu tidak dapat menjamin kekal dan aktual sepanjang zaman. Ini berarti kelambatan berlakunya al-Qur'an di semua lini, tempat dan zaman. Hanya dengan menghilangkan sikap taklid menggantikannya dengan Ijtihad, kita dapat dengan mudah dan sempurna mempetautkan hukum adat dengan kehendak Ilahi. Oleh karena itu fiqih yang ada sekarang ini ada yang perlu dikaji ulang. Hazairrin mencontohkan, kitab-kitab yang kita pelajari sekarang di Indonesia adalah kitab-kitab fiqih yang ditulis lima atau enam abad yang lalu, yang merupakan ekspresi kultur tertentu di sekitar Timur Tengah. Jadi selain sudah tua, kitab-kitab yang kita pelajari itu mengandung ekspresi Timur Tengah. Artinya kitab-kitab fiqih itu bersifat partikularistik, bersifat lokal, dan bukan bersifat universal.

Sehubungan dengan itu, Hazairin berharap agar dari institusiinstitusi pendidikan yang ada akan lahir mujtahid-mujtahid yang bukan

${ }^{15}$ Iskandar Ritonga, Hazairin Gelar Pangeran..., hlm. 69 
Idris Mahmudy, Metodologi Pembaharuan Hukum Islam dalam Perspektif ...

hanya memenuhi persyaratan sebagai seorang mujtahid tetapi juga menguasai ilmu-ilmu kemasyarakatan, ilmu hukum modern, ilmu antropologi, sehingga seorang mujtahid dalam dirinya menyatu kemampuan sebagai seorang jurist (ahli hukum) modern, sekaligus tampil sebagai ulama modern. Dengan kata lain jurist modern saja tidak akan sanggup menjalankan tugasnya dalam masyarakat Islam, meskipun dia diberi pelajaran dalam hukum Islam, karena hukum Islam yang diperolehnya hanya sedikit sekali, sedangkan ilmu alatnya masih dapat dikuasai dengan menggali sendiri atau dengan pelatihan. Ilmu keislaman tidak diperoleh pada fakultas hukum biasa. Pada sisi lain, ulama saja meskipun ia ulama modern, tetapi tidak mengetahui ilmu hukum modern tidak pula akan sanggup melayani kebutuhan masyarakat Islam. Ternyata kata Hazairin pengaruhnya sangat sedikit, karena ilmu kemasyarakatannya sangat sedikit dan pengertian ilmu hukumnya sangat terbatas pula. ${ }^{16}$

Prototipe yang diinginkan Hazairin inilah yang selalu diperlukan di era modern sekarang ini, yang dibutuhkan adalah ahli-ahli yang mampu membahasakan hukum-hukum Islam baik yang terdapat dalam al-Qur'an dan Hadis maupun yang terdapat dalam kitab-kitab fiqih, ke dalam bahasa undang-undang modern yang aktual, rasional dan sistimatis. Menurut penulis, UIN SUSKA Riau berpotensi untuk melahirakan cita-cita dan dambaan Hazairin, karena UIN memiliki para ilmuan yang berwawasan luas menembus hampir ke semua disiplin ilmu dan tidak lagi tersekat oleh Mazhab tertentu apatah lagi kita diera ini, dihadapkan dengan kasus-kasus kontemporer (anNawazil dan al-waqa’i fiqhiyah)

\section{Hazairin Menggagas Mazhab Indonesia}

Hazairin mengikuti jejak Hasbi Ash-Shiddieqy (1904-1975) ia mengajukan gagasan fikih Indonesia, sehingga ke depan perlu dilahirkan Mazhab Indonesia, Mazhab baru yang sesuai dengan kepribadian bangsa Indonesia dan kebutuhan zaman, dengan selalu

${ }^{16}$ Abdul Azis Dahlan, Ensiklopedi Hukum..., hlm. 538
A1-Fikra: Jurnal Ilmiah Keislaman, Vol. 5, No. 2, Juli-Desember 2006

merujuk kepada al-Qur'an dan Sunnah. Mazhab ini tidak hanya merujuk kepada Mazhab Syafi'i tetapi juga kepada Mazhab-mazhab lainnya. Bagaimana bentuk Mazhab Indonesia yang diinginkan Hazairin itu. Dalam pandangannya Mazhab Indonesia itu adalah Mazhab Syafi'i yang diperbarui. Beberapa masalah yang perlu diperbarui dalam ketentuan-ketentuan Mazhab Syafi'i itu antara lain adalah. Pertama mengenai zakat dan baitulmal yang harus disesuaikan dengan tuntutan modern dalam negara Pancasila. Kedua masalah perkawinan yang membutuhkan beberapa perbaikan, selaras dengan perkembangan zaman. Kemudian perlunya pembentukan masyarakat yang diridhai Allah, yaitu masyarakat yang bercorak parental (bila teral). Sedangkan masalah terakhir untuk saat ini adalah masalah kewarisan yaitu kewarisan yang bercorak parental.

\section{Kewarisan Bilateral}

Hazairin dalam rangka mewudkan mazhab Indonesia berusaha merumuskan kewarisan yang menurutnya bercorak bilateral. Ada tiga hal yang penting yang selalu diangkatnya dalam setiap bahasan masalah kewarisan yaitu mengenai kewarisan bilateral, kedudukan mawali(ahli waris pengganti) dan kalalah (ahli waris yang punah)

Pemikiran yang kontroversi di bidang kewarisan ini mengundang kritik dan polemik. Polemik pertama terjadi antara Hazairin dengan $\mathrm{H}$ Toha Jahja Omar, M.A (Mantan Dekan Fakultas Ushuluddin IAIN Jakarta dan anggota MPRS), Prof H. Mahmud Yunus (Mantan Dekan Fakultas Tarbiyah IAIN Jakarta dan Mantan Rektor IAIN Imam Bonjol Padang). Polemik ini berawal dari pemikirannya tentang hukum kewarisan bilateral. Menurut Hazairin sistem kekeluargaan dan sistem kewarisan yang dikehendaki al-Qur'an adalah sistem parental atau bilateral, bukan unilateral (patrilineal atau matrilineal). Al-Qur'an menurutnya anti terhadap masyarakat unilateral (klan). Teori ini digali Hazairin dari Surat An Nisa', ayat 22, 23 dan 24. Berdasarkan ayat-ayat tersebut, ia berkesimpulan bahwa masyarakat yang dikehndaki alQur'an adalah masyarakat parental. Oleh karena itu sistem kewarisannya juga harus bercorak parental. Teori ini menutut Anwar Haryono, sebagaimana dikutip oleh Iskandar Ritonga, meskipun 
Idris Mahmudy, Metodologi Pembaharuan Hukum Islam dalam Perspektif ...

bersumber dari al-Qur'an belum banyak dikenal oleh masyarakat Indonesia yang umumnya menganut Ahlussunnah wal Jama'ah (sunni). Teori ini merupakan sesuatu yang baru. ${ }^{17}$

Teori ini dipresentasikan Hazairin setelah melihat kenyataan yang ada di Indonesia dimana terdapat komflik antar figh Ahlussunnah dan hukum Adat yang terus berkepanjangan hingga sekarang. Fiqh Ahlussunnah menurutnya terbentuk dalam kebudayaan Arab yang bersendikan sistem kekeluargaan patrilineal dalam suatu masa dimana bentuk-bentuk masyarakat di dunia ini belum jelas dikaji dan ditemukan orang, sehingga para Mujtahid Ahlussunnah itu juga belum mungkin memperoleh bahan perbandingan mengenai sistem kewarisan yang dapat dijumpai dalam berbagai bentuk masyarakat.

Meskipun hukum kewarisan Sunni itu bercorak patrilineal, namun dalam kenyataan terdapat juga komflik antara hukum kewarisan patrilineal Sunni itu dengan kewarisan patrilineal yang ada di Indonesia, apalagi dengan masyarakat patrilineal dengan bilateral. Menurut Hazairin komflik-komflik itu bukanlah disebabkan kitab suci al-Qur'an, tetapi lebih oleh ikhtilaf manusia belaka. Kareana itu beliau menunjukkan kemauan Tuhan yang terdapat dalam al-Qur'an mengenai hukum kewarisan yang bersifat bilateral itu.

Karena teori yang diprsentasikan Hazairin itu terbilang teori baru, maka apakah ada pertentangan antara teori Hazairin dengan paham Ahlussunnah?. Dari segi ajaran murni memang tidak, karena kedua-duanya berdasarkan al-Qur'an dan Sunnah. Perbedaan terjadi dalam pemahaman dan penerapannya pada hal-hal yang tidak tegas diatur dalam al-Qur'an. Hazairin mendasarkan teorinya pada pandangan antropologi sosial Indonesia, kenyataan masyarakat Indonesia memang demikian, sedangkan Ahlussunnah walaupun pada waktu itu ilmu antropologi sosial belum lahir, namun paham mereka pun didasarkan pada kenyataan sosial masyarakat Arab. ${ }^{18}$

Dari larangan-larangan yang tercantum dalam al-Qur'an tentang perkawinan, berdasarkan kategori-kategori antropologi mengenai

17 Ibid, hlm. 539

${ }^{18}$ Alyasa Abubakar, Abli waris Sepertalian Darah, (Jakarta: INIS, 1998), Cet 1,
Al-Fikra: Jurnal Ilmiah Keislaman, Vol. 5, No. 2, Juli-Desember 2006

kekerabatan, Hazairin juga melihat tidak adanya larangan crosscausins dan parallel causins marriage, berarti tidak ada pula kewajiban untuk menjalankan perkawinan eksogami dan kewajiban perkawinan endogami.

Dari sinilah Hazairin mengambil kesimpulan setelah observasi dengan landasan teorinya adalah pendekatan hasil ilmu kontemporel (antropologi) ketika melakukan ijtihad hukum-hukum fikih (kewarisan), dalam rangka menciptakan sebuah sistem yang padu dan menyeluruh. Hazairi menganggap kelahiran dan perkembangan ilmu antropologi telah membuka peluang untuk melihat ayat-ayat tentang kewarisan dalam kerangka yang lebih luas, yaitu sistem kekeluargaan dalam berbagai masyarakat di dunia. Temuan ini menurut Hazairin perlu dimunculkan kepada masyarakat, karena al-Qur'an kedudukannya bersifat universal dan pedoman untuk semua manusia di semua tempat dan waktu. Hazairin sangat tidak puas terhadap pandangan yang sempit yang memandang ayat-ayat al-Qur'an tentang kewarisan berlaku hanya untuk masyarakat adat Arab pada zaman Nabi saw saja yang menyebabkan berbenturan dan dirasa asing oleh masyarakat yang sistem kekeluargaan berbeda. Menurut beliau sistem kemasyarakatan yang dikehendaki al-Qur'an adalah yang bilateral. Contohnya adalah perkawinan antara Ali dan Fatimah yang samasama berasal dari satu klan. Tetapi menurut Hazairin, masyarakat bilateral yang dikehendaki al-Qur'an itu bukanlah masyarakat biasa, melainkan masyarakat bilateral sui generis yaitu masyarakat bilateral yang berbeda dalam jenisnya. ${ }^{19}$

Setelah masalah sistem kewariasan bilateral, Hazairin juga mengemukakan mengenai ahli waris pengganti (mawali) (plaatsvervulling). Tentang mawali ini, Hazairin mengatakan bahwa pemakaian "ahli waris pengganti" sebagai padanan mawali, sesungguhnya tidak begitu tepat, namun istilah itu digunakan juga karena "perkataan ahli waris pengganti" terdapat dalam hukum adat.

19 Badhawi, Konsepsi Hazairin Tentang Hukum Kewarisan Islam, (Yogyakarta: IAIN Sunan Kalijaga, 1988). hlm. 3 
Idris Mahmudy, Metodologi Pembaharuan Hukum Islam dalam Perspektif ...

Masalah ahli waris pengganti (plaatsvervulling) ini muncul karena Hazairin merasakan adanya ketidakadilan dalam pembagian warisan yang ada selama ini, yakni bahwa cucu perempuan yang ayahnya meninggal terlebih dahulu, tidak mendapat harta warisan dari peninggalan kakeknya. Dalam masalah ini Ulama Ahlussunnah dan juga syi'ah sepakat bahwa anak laki-laki menghijab (menutup) cucu laki-laki dan cucu perempuan. Oleh karenanya cucu yang ayahnya meninggal terlebih dahulu, meskipun sangat berjasa dalam mengurus kakeknya karena ada anak kakek (saudara ayah) yang masih hidup yang menghijabnya, meskipun paman tersebut tidak pernah berjasa mengurusi ayahnya. Menanggapi hal ini Hazairin memberi penafsiran baru terhadap Surah An-Nisa' ayat 33. Ia mengartikan mawali dalam ayat itu dengan "ahli waris pengganti", dalam pengertian ini cucu dalam kasus di atas berkedudukan sebagai pengganti ayahnya

Gagasan ini dimaksudkan sebagai upaya mengisi kekosongan yang terdapat dalam sistem hukum kewarisan Islam yang telah dianggap mapan, padahal persoalan ini masih memerlukan penafsiran ulang, karena tidak diatur secara tegas (qath'i) dalam al-Qur'an. Akan tetapi gagasan yang dikemukakan Hazairin itu kurang mendapat sambutan dari Ulama Indonesia, kecuali dalam kalangan terbatas, meskipun mereka menyadari bahwa dalam kasus tersebut gagasan Hazairin lebih dirasakan adil. Hal ini lebih disebabkan para ahli fikih Indonesia merasa enggan untuk mngadakan kaji ulang terhadap hal yang sudah dianggap mapan atau standar, meskipun dalil untuk menetapkannya tidak qath'i . Pemikiran Hazairin mengenai ahli waris pengganti ini, kelihatannya mendapat dukungan dari Prof. Dr. Amir Syarifuddin, sebagaimana dikutip oleh Iskandar Ritonga, dalam Mimbar Hukum nomor 44, 1999. Amir menjelaskan bahwa dikesampingkannya cucu melalui anak perempuan dari deretan ahli waris (kecuali sebagai zawil arham) dalam keadaan tertentu dirasakan ketidakadilan; terutama di kalangan masyarakat matrilineal Minang Kabau, yang menganggap justru anak dari anak perempuan itulah yang
Al-Fikra: Jurnal Ilmiah Keislaman, Vol. 5, No. 2, Juli-Desember 2006

benar-benar disebut sebagai cucu, sedangkan cucu melalui anak lakilaki tidak disebut cucu melainkan dikenal dengan anak pisang. ${ }^{20}$

Gagasan Hazairin tentang ahli waris pengganti ini sudah menjadi rumusan Kompilasi Hukun Islam (pasal 185 ayat (1) dan (2) KHI)

Hazairin juga mengangkat masalah "kalalah", yang menurutnya keadaan seseorang yang meninggal dunia tanpa meninggalkan keturunan (mati punah) baik anak laki-laki maupun anak perempuan. Pengertia ini dikaji dari Surat An Nisa' ayat 12 dan 176. Rumusan baru yang dikemukakan Hazairin adalah dengan memperluas pengertian anak menjadi keturunan, sebagai hasil penggabungan ayat 12 dan 176 tersebut dengan pengertian yang terdapat dalam An-Nisa' ayat 33, sehingga pengertian "kalalah" adalah" keadaan seseorang yang mati punah" artinya mati dalam keadaan tidak berketurunan. Dalam sistem bilateral yang dianut oleh al-Qur'an, maka keturunan artinya setiap orang dalam garis lurus ke bawah baik melalui garis laki-laki maupun melalui garis perempuan.

Pemikiran Hazairin d ibidang Peradialan Agama, hukum perkawinan, serta hukum kewarisan sudah sedemikian jelas dan mendapat perhatian yang demikian luas, maka tidak demikian halnya dengan masalah zakat, baitul mal, dan emansipasi wanita. Dalam bidang zakat sangat perlu adanya Undang-undang tentang zakat dan pemikiran ini telah tertuang dalam Undang-undang Nomor 38 Tahun 1999 tentang pengelolaan zakat, walaupun masih perlu disempurnakan.

Dalam rangka mewujudkan Mazhab Indonesia, Hazairin menyingkap pemikirannya di bidang pidana Islam yang termasuk pemikiran yang sangat langka, karena dialah satu-satunya pemikir Islam Indonesia yang secara mengagumkan menawarkan sebuah konsep "negara tanpa penjara", sebuah konsep yang menurut ukuran umum sangat mustahil terwujud di negara ini. Hazairin dengan konsep ini, ingin menggambarkan bagaimana al-Qur'an dan Rasulullah mengatur negara tanpa penjara dengan menjalankan sistem pidana Islam. Negara tanpa penjara menurut Hazairin telah dimulai sejak lima

20 Amir Syarifuddin, Pembaharuan Pemikiran Dalam Hukum Islam, (Padang: Angkasa Raya, 1993), Cet 1, hlm. 134. 
Idris Mahmudy, Metodologi Pembaharuan Hukum Islam dalam Perspektif ...

belas abad yang lalu yaitu sejak Nabi Muhammad diangkat menjadi Rasul. Berdasarkan analisisnya ajaran al-Qur'an dan Hadis ternyata tidak pernah menetapkan wajib adanya hukuman penjara. Al-Qur'an tidak menetapkan dan mewajibkan kepada umat Islam untuk menyediakan penjara, bahkan tidak pernah menganjurkan dan mengajarkannya. Al-Qur'an telah menetapkan jenis-jenis hukuman terhadap berbagai tindak pidana yaitu, hukuman mati, hukuman dera (cambuk), hukuman denda (ganti rugi), hukuman potong tangan, hukuman buang (dipindahkan ke daerah lain), sehingga orang yang terhukum itu dapat hidup dalam masyarakatnya yang baru untuk memperbarui dan memperbaiki cara hidupmya.

Sehubungan dengan gagasannya mengeni pidana Islam, Hazairin mengutarakan perlunya undang-undang pidana Islam untuk diberlakukan kepada umat Islam Indonesia. Yang menjadi pertanyaan adalah, apakah mungkin diterapkan hukum pidana Islam di Indonesia?. Menurut Hazairin way not, pasal 29 ayat(1) UUD 1945 membuka peluang untuk itu dan berdasar pasal itu pula Hazairin mengatakan negara mesti menjalanka hukum agama bagi pemelukpemeluknya. Ini juga berarti untuk menerapkan hukum pidana Islam di Indonesia kepada pemeluknya, minimal hukum yang berlaku di Indonesia tidak bertentangan dengan hukum Islam.

Menurut penulis ditinjau dari segi politik hukum gagasan Hazairin tentang perlunya penerapan hukum pidana Islam di Indonesia kepada pemeluk-pemeluknya, kurang strategis karena di Republik ini, ketidaksenangan kepada merek Islam bukan hanya dari luar Islam tetapi juga dari muslim fobia, karena itu andalan Islam di Indonesia bukan lebel Islam akan tetapi menurut penulis perjuangan Islam Indonesia bergeser dari merek dan lebel kepada "mentransformasikan" makasid Syari'ah ke dalam rancangan undangundang termasuk hukum pidana Islam. Perkembangan politik hukum pidana di Indonesia suadah mengalami pertumbuhan untuk memperhatikan pengaruh dari faktor nilai-nilai kemasyarakatan dan keagamaan. Untuk memenangkan perjuangan ini, diperlukan aktifitas para ulama dan cendikiawan muslim untuk ikut berperan pada setiap penyusunan rancangan undang-undang, sehingga makasid Syari'at Islam tidak kececeran dan dengan cara inilah dapat menjalin hukum
Al-Fikra: Jurnal Ilmiah Keislaman, Vol. 5, No. 2, Juli-Desember 2006

pidana Isalam dengan hukum pidana nasioanal sesuai dengan mayoritas rakyatnya beragama Islam yang memerlukan perlindungan hukum yang tidak bertentangan dengan prinsip makasid Syariah . Dengan strategi ini unsur agama dapat mewarnai hukum pidana positif di Indonesia.

\section{Metodologi Pembaruan Hukum}

Metode ilmiah adalah prosedur dalam mendapatkan pengetahuan yang disebut ilmu. Jadi ilmu merupakan pengetahuan yang didapatkan lewat metode ilmiah. Karena idealnya dari pengetahuan adalah untuk memperoleh interrelasi yang sistematis dari fakta-fakta dengan menggunakan pendekatan kesangsian sistematis, oleh karena itu penelitian dan metode ilmiah mempunyai hubungan yang sangat erat, kalau tidak dikatakan sama. Hazairin dalam rangka pembaruan hukum Islam telah melakukan langkah pertama dengan suatu "teori" yang merupakan suatu sistem yang berisikan proposisi-proposisi yang telah diuji kebenarannya. Karena Hazairin berpedoman kepada teori, maka ia dapat menjelaskan aneka macam gejala sosial yang dihadapinya, walaupun tidak selalu berarti adanya pemecahan terhadap masalah yang dihadapi. Kedua Hazairin menggunakan "metodologi", karena dengan metodologi seorang ilmuan mempunyai pedoman tentang cara-cara mempelajari, menganalisa, dan memahami lingkunganlingkungan yang dihadapinya. Ia melakukan usaha untuk bergerak dari teori ke pemilihan metode. Ketiga Hazairin mendasarkan pemikirannya pada kerangaka sistem masyarakat yang menjadi pusat perhatiannya, walaupun hanya menelaah salah satu komponen saja, dia harus tetap menyadari bahwa komponen tersebut mempunyai hubungan fungsionil dengan komponen-komponen lainnya

Hazairin memilih untuk melihat hukum sebagai perwujudan dari nilai-nilai sosial bangsa Indonesia, maka pilihan tersebut akan membawa Hazairin kepada metode yang bersifat idealis. Metode ini akan senantiasa berusaha untuk menguji hukum yang harus mewujudkan nilai-nilai. Salah satu pemikiran utama dalam hukum yang sudah berjalan adalah berusaha memahami arti dari keadilan. Inilah satu contoh dari metode ideologis. 
Idris Mahmudy, Metodologi Pembaharuan Hukum Islam dalam Perspektif ...

Hazairin memilih untuk melihat hukum sebagai seatu sistem peraturan-peraturan yang abstrak, karena itu perhatiannya terpusat pada hukum sebagai suatu lembaga yang benar-benar otonom. Pemusatan perhatian yang demikian ini akan membawa Hazairin kepada penggunaan metode normatif dalam menggarap hukum dengan cara pembahasan yang bersifat analitis, karena itu metode ini disebut sebagai normatif analitis. Hazairin juga memandang bahwa hukum sebagai alat untuk mengatur masyarakat dengan demikian ia juga memilih metode sosiologis untuk mencapai tujuan serta memenuhi kebutuhan-kebutuhan kongkret dalam masyarakat, berangkat dari kasus ke kasus dan segala prosesnya yang tak terelakkan dan akan berlangsung melalui silogisma deduksi.

\section{Kesimpualan}

Pemikiran-pemikiran Hazairin terus dibicarakan dan diperbincangkan dalam berbagai kesempatan, baik oleh pemerhati hukum Islam dan hukum umum, maupun di lingkungan Fakultas Syari'ah IAIN dan UIN dan Fakultas Hukum lainnya di Inonesia

Kewarisan bilateral yang merupakan pembaruan hukum kewarisan di Indonesia diterima sepenuhnya oleh Universitas Indonesia (UI) yang diputus dalam seminar nasional I tahun 1963

Keinginan Hazairin untuk mempebaiki "wajah hukum” yang ada di tengah umat Islam Indonesia, agar semaksimal mungkin disesuaikan dengan tuntunan al-Qur an, tanpa mengikuti adat istiadat masyarakat Arab yang tidak sesuai dengan budaya dan nilai yang hidup di Indonesia.

Hazairin seorang penggagas Mazhab Fiqh Indonesia, dan yakin mulai terwujud karena disambut oleh Teoritisi dan Praktisi hukum Islam di Indonesia.

Metologi pembaruan hukum yang digunakan Hazairin adalah "deduktif” dengan pendekatan normatif analisis serta pendekatan sosiologis antropologis

\section{Bibliografi}

Al-Fikra: Jurnal Ilmiah Keislaman, Vol. 5, No. 2, Juli-Desember 2006

Abubakar, Al-yasa, Abli waris Spertalian Darah, (Jakarta: INIS, 1998)

Ali, Muhammad Daud, Hukum Islam, Jakarta: PT.Raja Grafindo Persada, 2004)

Arifin, Bustanul, Prospek Hukum Islam, (Jakarta: PP IKAHA, 1994).

Badhaw, Konsepsi Hazairin Tentang Hukum Kewarisan Islam, (Yogyakarta: IAIN Sunan Kali Jaga, 1988)

Dahlan, Abdul Aziz, Ensiklopedi Islam, (Jakarta: PT. Ichtiar Baru Van Hoeve, 2001)

Gafir, Abdul, Pemikiran Prof. Dr. Hazairin, S.H, dalam Pembaruan Hukum, (Jakarta: t.p., t.t.)

Hazairin, Hendak Kemana Hukum Islam, (Jakarta: Jakarta, 1976) cet.3

.............., Hukum Kekeluargaan Nasional, (Jakarta: Tintamas, 1982) cet. 3

, Hukum Kewarisan Bilateral Menurut Qur'an dan Hadis, (Jakarta: Tintamas, 1982), cet. 3

Tujuh Serangkai Tentang Hukum, (Jakarta: Tintamas, 1974)

Ismuha, Pengganti Tempat Dalam Hukum Waris, (Jakarta: t.p. tt.,)

Khair, Damra, Hukum Kewarisan Islam Pemahaman Hazairin, (Jakarta: Fakultas Pascasarjana IAIN Syarif Hidayatullah, 1988).

Soekanto, Soerjono, Pengantar Penelitian Hukum, (Jakarta: UI Press, 2005)

Sunggono, Bambang, Metodologi Penelitian Hukum, (Jakarta: PT. Raja Grafindo Persada, 2002)

Syarifuddin, Amir, Pembaharuan Pemikiran Dalam Hukum Islam, (Padang: Angksa Raya, 1993)

Thalib, Sayuti, Receptio A Contrario, (Jakarta: Bina Aksara, 1985) 